\title{
EVALUATION OF SOME TRICHODERMA SPECIES IN BIOLOGICAL CONTROL OF POTATO DRY ROT CAUSED BY FUSARIUM SAMBUCINUM FUCKEL ISOLATES
}

\author{
AYDIN, M. H. \\ Department of Plant Protection, Faculty of Agriculture, Siirt University, Siirt, Turkey \\ (e-mail: hadiaydin@siirt.edu.tr; phone: +90-536-599-9794) \\ (Received $11^{\text {th }}$ Sep 2018; accepted $22^{\text {nd }}$ Nov 2018)
}

\begin{abstract}
Fusarium dry rot of potato is a major disease caused by several Fusarium species, and Fusarium sambucinum Fuckel is considered to be the most aggressive species in worldwide, including Turkey. Biological control based on the use of microorganisms to suppress tuber diseases offers an attractive alternative that has gained great attention due to the significant potential. Several fungal biocontrol agents have been used in plant disease control, and Trichoderma group has been reported as effective against tuber pathogens such as $F$. sambucinum. This study was carried out under in vitro and in vivo conditions. During in vitro conditions, the effects of fifteen Trichoderma isolates ( $T$. asperellum ÖT1; T. viride VG18; T. viride VG19; T. harzianum TZ16, T. harzianum LO52; T. gamsii VG47; T. gamsii VG48; T. virens KB31; T. strigosum LO43, T. strigosum LO8; T. neokoningii A15; T. atroviride VG3; T. tomentosum VG2; T. Inhamatum KEB12; $T$. hamatum ÖT16) were studied against three isolates of $F$. sambucinum (Fs2, Fs3 and Fs4) in PDA medium by using duel culture technique in incubation at 22 $\pm 24^{\circ} \mathrm{C}$. The most effective isolates were $T$. virens KB31, T. gamsii VG47, T. hamatum ÖT16, $T$. asperellum ÖT1, T. harzianum LO52, T. atroviride VG3, respectively. During in vivo conditions, potato tubers, CV. Desire were wounded and inoculated with $1 \mathrm{ml}$ of Trichoderma isolates suspensions $\left(10^{7}\right.$ spores $\left.\mathrm{mL}^{-1}\right), 24 \mathrm{~h}$ prior inoculation by $F$. Sambucinum. Reduction rate of dry rot in tubers was recorded during 5-6 weeks of incubation at $20-24{ }^{\circ} \mathrm{C}$ to compare with control treatments. Tuber dry rot was reduced by the antagonistic fungal isolates with different rates. The most effective isolates were $T$. viride VG18, T. asperellum ÖT1, T. harzianum TZ16, $T$. virens KB31 and T. inhamatum KEB12, respectively. Potato tubers were also treated with commercial seed fungicides named Celest-Max ${ }^{\circledR}$ (Fludioxonil, SC $100 \mathrm{~g} / \mathrm{l}$ )] and Quadris ${ }^{\circledR}$ (Azoxystrobin, SC $250 \mathrm{~g} / \mathrm{l}$ ). The results revealed that Fludioxonil treatments were more effective compared to Azoxystrobin treatments and the biological control agents.
\end{abstract}

Keywords: potato dry rot, Fusarium sambucinum, virulence, Trichoderma sp., biocontrol

\section{Introduction}

Potato dry rot disease is one of the major diseases of potato tubers (Solanum tuberosum L.) both in storage and planting. The rate of tubers infected in storage reaches up to $60 \%$. Yield losses attributed to dry rot in field is almost $25 \%$ (Hanson et al., 1996; Stevenson et al., 2001). Primary causes of potato dry root disease are several species of Fusarium such as $F$. sambucinum Fuckel, $F$. solani (Mart.) Sacc, $F$. avenaceum (Fr.) Sacc, F. culmorum (W.G. Sm.) Sacc, and F. oxysporum Schltdl (Boyd., 1972; Nelson et al., 1981, 1983; Hanson et al., 1996; Eken et al., 2000; Borca and Carmen, 2013; Stefańczyk et al., 2016; Aydın et al., 2016). Chemical control strategy sometimes may not be quite effective and economical against dry rot in potato. Therefore, alternative methods are needed to control the plant diseases. Trichoderma is known as the most widely used antagonists in biological control.

Current study was carried out with a total of 15 isolates and ten Trichoderma species. The efficacy of Trichoderma species against 3 isolates of $F$. sambucinum (Fs2, Fs3, Fs4) was investigated by duel culture in nutrient media and tuber application methods. Thus, some effective antagonists have been identified. According to our information, 
this is the first study on biological control using a large number of Trichoderma species against dry rot disease of potato.

\section{Review of literature}

Fusarium sambucinum Fuckel - teleomorph Giberella pulicaris most (Fr.) Sacc. is one of the most common and aggressive species found in potato tubers throughout the world (Boyd, 1972; Secor and Salas, 2001; Choiseul et al., 2001; Cullen et al., 2005; Sun et al., 2008; Eken et al., 2000; Aydin et al., 2016; Peters et al., 2008). This pathogen also produces trichothecene toxins which are secondary metabolites and cause various problems on humans and animals (Senter et al., 1991).

Fungi is mostly transported by tubers. However, Fusarium species such as $F$. sambucinum are common in most potato grown soils and can survive as resistant spores free in soil for a long time (Adams and Lapwood, 1983; Secor and Salas, 2001; Carnegie et al., 1998).

The disease can temporarily be suppressed by some postharvest applications to the tubers. However, when tubers exposed to the pathogen in soil, no measures can be taken. Previous studies indicated that fungicide applications during postharvest period cause resistance to $F$. sambucinum after a while and thus they may not be efficient enough (Hide et al., 1992; Desjardins, 1995; Peters et al., 2001; Gonzalez et al., 2002; Daami-Remadi et al., 2006; Gachango et al., 2012). A large number of studies have been conducted to identify cultivars resistant to dry rot disease of potato caused by $F$. sambucinum, but commercial potato cultivars are often susceptible to this disease (Schisler et al., 1997; Jellis, 1975; Langerfeld, 1979; Hooker, 1981; Jellis and Starling, 1983; Wastie et al., 1989; Ayed et al., 2006b; Aydın and İnal, 2018). Therefore, effective tuber treatments along with other applications prior to planting or during storage may reduce the severity of dry rot disease.

Several studies have been carried out on biological control of plant pathogens. The studies showed that Trichoderma species can be used as biological control agents against pathogens in soil microflora, especially in plant roots and tubers (Boosalis, 1964; Wilhelm, 1973; Lockwood, 1977; Cook and Baker, 1983; Whipps et al., 1993; Elad, 2000; Harman et al., 2004; Chaube et al., 2002; Aydın and Turhan, 2009). The role of Trichoderma species in biological control can be explained by interactions of biological control mechanisms such as antibiosis, hyperparasitism and competition (Kredics et al., 2003). When Trichoderma species are applied to tuberous plants, they colonize on newly formed organs of plants (tubers, roots and stolons) during the production season and maintain their activities (Harman, 2000; Howell, 2003; Aydin and Turhan, 2013). Some studies have reported that Trichoderma species can successfully control important tuber and soilborne phytopathogenic fungi such as $F$. sambucinum and Rhizoctonia solani Kuhn (Chet and Baker, 1981; Elad et al., 1980; Bell et al., 1982; Manczinger et al., 2002; Aydin and Turhan, 2013). A large number of studies have been conducted to investigate the effects of Trichoderma species on dry rot disease of potato caused by $F$. sambucinum. Some of these studies are; T. viride Pers. (Sadfi et al., 2001; Ayed et al., 2006a); T. harzianum Rifai. (Cherif et al., 2001; Ru and Di., 2012. Wharton and Kirk, 2014) T. harzianum, T. viride (Daami-Remadi et al., 2006); Trichoderma spp. (Schisler et al.,1998); T. longibrachiatum Rifai, T. atroviride Bissett., T. virens (G. virens) J.H., Mill., Giddens \& A.A Foster (Ru and Di., 2012). The studies generally reported suppressing the dry rot disease of potato at certain rates. 


\section{Material and methods}

\section{Microorganisms}

\section{Pathogen}

Three isolates of F. Sambicunum (Fs2, Fs3, Fs4) used in the study were obtained from the isolate collection of Phytopathology laboratory in the Department of Plant Protection, Faculty of Agriculture at Siirt University, Turkey. The isolates were isolated from potatoes with signs of dry rot disease. Identifications were performed by classical and DNA based technics, and pathogenicity of the isolates have been previously determined (Aydın et al., 2016; Aydın and İnal, 2018). Before being used in studies, clean tubers were contaminated with the isolates and isolates were re-isolated. Thus, the virulence of the isolates was protected. Isolates purified with single spore culture and stored at $+4{ }^{\circ} \mathrm{C}$ were used in the study after culturing for 15 days in the dark at $15{ }^{\circ} \mathrm{C}$ in Potato Dextrose Agar (PDA, $38 \mathrm{~g}$ and $1 \mathrm{~L}$ completed with sterile water).

\section{Antagonists}

Trichoderma species (Table 1) were selected from isolate collection of Phytopathology laboratory in the Faculty of Agriculture at Siirt University. These isolates were previously isolated from soils in different regions of Turkey and identified both based on colony and conodial morphology (Aydin and Turhan, 2009). Isolates were stored at $+4{ }^{\circ} \mathrm{C}$ in oblique agar tubes containing PDA and used in the study after culturing in Potato Dextrose Agar (PDA) medium for 15 days at $24{ }^{\circ} \mathrm{C}(12 \mathrm{~h}$ dark, $12 \mathrm{~h}$ light).

\section{Potato cultivars}

The potato variety, cv. DESİRE ${ }^{\circledR}$ known to be sensitive to $F$. Sambucinum was used in the study (Aydin and İnal, 2018). The certified tubers weighing 80-100 g and 50$60 \mathrm{~mm}$ in diameter, which were not contaminated with any disease, were obtained from a field harvested in the same year.

\section{Antagonism in vitro (duel culture)}

Three isolates of $F$. sambicunum (Fs2, Fs3, Fs4) and Trichoderma species were grown on PDA and discs with a diameter of $8 \mathrm{~mm}$ were taken from the margins using a cork borer. The discs were planted (duel culture techniques) on the opposite side of the plate at equal distance from the periphery. The planting process was performed at the same time to each petri dish containing $20 \mathrm{ml}$ of PDA medium in dotted form. Experiments were performed in an incubator at $22-24{ }^{\circ} \mathrm{C}$. The study was conducted in 6 replications.

The evaluation time was determined based on the time that the pathogen colony was first fully covered by an antagonist. The mycoparasitic activity considering the rate and intensity of $F$. sambicunum colonization by the antagonist was evaluated according to the scale suggested by Turhan (1990) (Table 1).

\section{Inoculation ad tuber treatment}

The tubers were thoroughly washed in tap water and then kept in 5\% sodium hypochlorite $(\mathrm{NaOCI})$ for $5 \mathrm{~min}$ prior to the treatments. They were washed twice in 
sterile water and allowed to dry on the drying paper for one day. Colonies taken from 7 to 10-day cultures of $F$. sambicunum isolates were placed into the $8 \mathrm{~mm}$ deep and $8 \mathrm{~mm}$ diameter holes drilled by an appropriate knife in the mid-belly of tubers. Water was added to the antagonistic Trichoderma grown in the PDA for a week, then scraped with a spatula, transferred to a double layer cheesecloth, and the spores were separated from the medium. The density of spore was counted with a haemocytometer slide in a microscope and adjusted to $1 \times 10^{6}$ spores $\mathrm{ml}^{-1}$. Carboxy methyl cellulose in an amount of $0.05 \%$ was added to the spore suspensions to strengthen the adhesion, and three drops of Tween 20 were added to ensure uniform distribution of spores in the suspension. Finally, the suspensions were kept in a shaker for $15 \mathrm{~min}$. to maintain the homogeneity. Twenty-four hours after placing the $F$. sambicumum colony into the tubers, $1 \mathrm{ml}$ of the prepared suspensions was added to the drilled holes, and the holes were covered with the tissues taken from the potatoes. Only sterile water and PDA parts were used for the untreated tubers. For comparison purposes, fungicides such as Celestine-Max ${ }^{\circledR}$ (Fludioxonil, $100 \mathrm{~g} \mathrm{~L}^{-1}$, Syngenta Crop Protection Inc.) registered against Rhizoctonia solani of potato in Turkey and Quadris ${ }^{\circledR}$ (Azoxystrobin, $250 \mathrm{~g} \mathrm{~L}^{-1}$, Syngenta Crop Protection Inc.) usually licensed to the late blight disease caused by Phytophthora infestans in potatoes and vegetables were used. Fungicides were mixed with water at the indicated doses $\left(20 \mathrm{ml} \mathrm{L}^{-1}\right.$ for Fludioxonil and $75 \mathrm{ml} 100 \mathrm{~L}^{-1}$ for Azoxystrobin) and $1 \mathrm{ml}$ was added into each hole drilled in tubers.

The treatments of experiment were 1) no treatment (Negative control), 2) treated only with F. sambicunum isolates (Fs2, Fs3, Fs4) (Positive control), 3) treated with Trichoderma species and pathogen isolates, and finally 4) treated with fungicides. All three tubers were considered as units and the experiment was set up with four replications in a randomized plot design. The tubers over a humidified cloth on a large plastic tray were placed in a climate cabinet set at $15-20{ }^{\circ} \mathrm{C}$. The experiments were conducted in the laboratories of Plant Protection Department, Faculty of Agriculture, Siirt University, Turkey.

\section{Evaluation of tuber treatments}

The tubers were cut longitudinally after 5 weeks of incubation; width (w) and depth (d) were measured, the penetration value was calculated using Equation 1 developed by Lapwood et al. (1984).

$$
\text { Penetration }(\mathrm{mm}):[\mathrm{w} / 2+(\mathrm{d}-6)] / 2
$$

The percent $(\%)$ effect of the treatments was evaluated according to the Abbott formula (Eq. 2), by comparing the values of positive control after computing the average values of each application.

$$
\text { Effect of applications }(\%): \frac{X-Y}{X} \times 100
$$

where:

$\mathrm{x}$ : Mean disease severity in positive control plots (\%)

$\mathrm{y}$ : Mean disease severity in treated plots (\%) 
Statistical analysis of the experiment was carried out by "JMP 8" statistical software (SAS Institute Inc.) and the differences among treatments were grouped by the LSD (LS Means Differences Student's t) test

\section{Results}

\section{Efficiency of antagonists in vitro}

The effects of Trichoderma species on F. sambicunum isolates (Fs2, Fs3 and Fs4) were presented in Table 1. Antagonists and pathogen isolates were cross-planted in dotted form at the same time on the PDA medium. The assessment was based on appearance of the first antagonist that completely covered the pathogen colony in the petri dish. This antagonist was considered to be a very strong hyperparasitic and the others were assessed according to the scale given in Table 1. The most efficient antagonists for $F$. sambicunum Fs1 were $T$. atroviride VG3, $T$. gamsii VG47, $T$. hamatum ÖT16 and $T$. viride VG18, respectively. The antagonists for $F$. sambicunum Fs2 were T. atroviride VG3, T. hamatum ÖT16, T. gamsii VG47 and T. viride VG18, and those for $F$. sambicunum Fs3 were $T$. atroviride VG3, T. gamsii VG47, $T$. strigosum LO43, T. viride VG18 and T. hamatum ÖT16, respectively. Weakly developed antagonist isolates on three $F$. sambucinum isolates were $T$. tomentosum VG2, T. neokoningii A15 and T. strigosum LO8, respectively (Table 1).

Table 1. Effects of in-vitro antagonists on F. sambucinum isolates (Fs2, Fs3, Fs4)

\begin{tabular}{|c|c|c|c|}
\hline Antagonists & F. sambucinum Fs 1 & F. sambucinum Fs2 & F. sambucinum Fs3 \\
\hline T. hamatum ÖT16 & VSH* $^{*}$ & VSH & VSH \\
\hline T. virens $\mathrm{KB} 31$ & $\mathrm{H}^{* * *}$ & $\mathrm{H}$ & $\mathrm{H}$ \\
\hline T. viride VG19 & $\mathrm{SH}^{* *}$ & $\mathrm{H}$ & SH \\
\hline T. viride $\mathrm{VG} 18$ & $\mathrm{SH}$ & $\mathrm{VSH}^{*}$ & SH \\
\hline T. harzianum LO52 & SH & SH & SH \\
\hline T. harzianum TUZ16 & $\mathrm{H}$ & SH & $\mathrm{H}$ \\
\hline T. strigosum LO8 & $\mathrm{H}$ & $\mathrm{H}$ & $\mathrm{H}$ \\
\hline T. inhamatum KEB12 & SH & SH & $\mathrm{H}$ \\
\hline T. asperellum ÖT1 & SH & VSH & SH \\
\hline T. gamsii VG47 & VSH & $\mathrm{SH}$ & $\mathrm{SH}$ \\
\hline T. tomentosum VG2 & $\mathrm{H}$ & $\mathrm{H}$ & $\mathrm{WH}^{* * * *}$ \\
\hline T. neokoningii A15 & $\mathrm{H}$ & $\mathrm{H}$ & WH \\
\hline T. atroviride $\mathrm{VG} 3$ & VSH & VSH & VSH \\
\hline T. strigosum $\mathrm{LO} 43$ & $\mathrm{H}$ & SH & SH \\
\hline T. gamsii VG48 & VSH & VSH & VSH \\
\hline
\end{tabular}

VSH*: Very strong mycoparasitism: Antagonist completely covers the colony of the pathogen $\mathrm{SH}^{* *}$ : Strong mycoparasitism: Antagonist shows a strong improvement over the pathogen colony $\mathrm{H}^{* * *}$ : Moderate mycoparasitism: The development of the antagonist on the pathogen colony is easily discernible

WH****: Poor mycoparasitism: Very poor development of antagonist on the pathogen colony is noticed 
Trichoderma isolates showed hyperparasitic character and inhibited the pathogen colony by growing over them (Table 1). Some antagonist isolates have also completely covered the pathogen isolates and they have demonstrated very strong hyperparasitic (VSH) features (Table 1). Some Trichoderma isolates showed very strong hyperparasitic (VSH) or strong hyperparasitic $(\mathrm{SH})$ features, while some isolates were only moderately hyperparasitic $(\mathrm{H})$ and they were less effective. The efficiency of antagonists showing strong hyperparasitic features were approximately close to each other against three isolates of $F$. sambucinum (Fs1, Fs2, Fs3). For example, $T$. atroviride VG3, T. gamsii VG47, T. gamsii VG48 and T. hamatum ET16 antagonists were the fastest and the most effective mycoparasites against three isolates of the pathogen. Images of antagonist growth on $F$. sambucinum isolates in PDA medium according to the duel culture method were shown Figure 1.

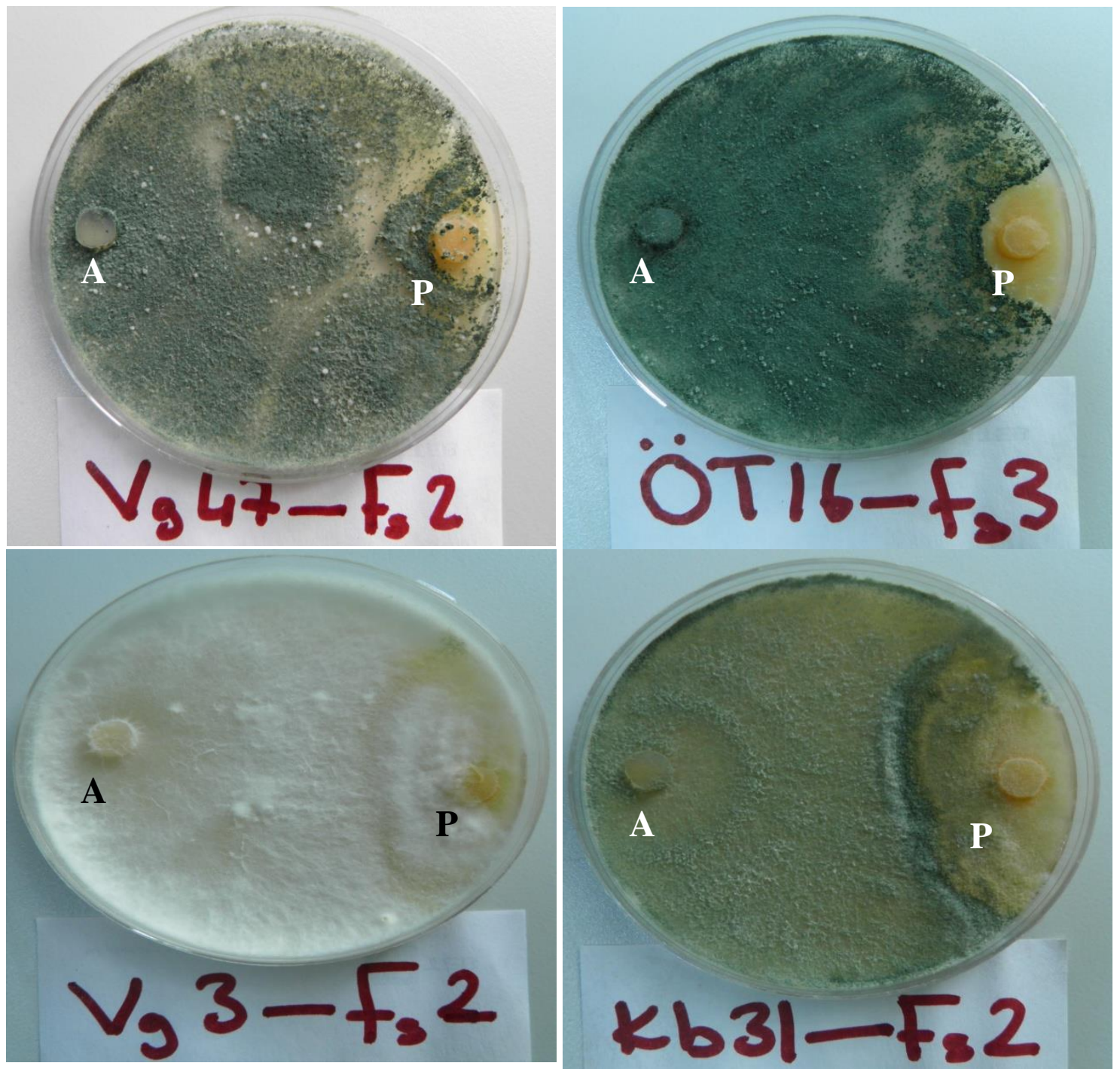

Figure 1. Images of some antagonist growth on F. sambucinum isolates in PDA medium according to the duel culture method [T. gamsii VG47- F. sambucinum 2 (VSH: Very strong mycoparasitism); T. hamatum ÖT16 - F. sambucinum 3 (VSH: Very strong mycoparasitism); $T$. atroviride VG3- F. sambucinum 2 (VSH: Very strong mycoparasitism); T. virens KB31- F. sambucinum 2 (H: Moderate mycoparasitism); A: Antagonist, P: Pathogen 


\section{Evaluation of tuber applications}

The efficacy of Trichoderma species on tubers against $F$. sambucinum isolates (Fs2, Fs3, Fs4) was presented in Table 2.

Table 2. The extent of suppressing ( $\mathrm{mm}$ ) and grouping of F. sambucinum isolates (Fs2, Fs 3, Fs4) on potato tubers of some fungicides and Trichoderma species

\begin{tabular}{|c|c|c|c|c|c|}
\hline No & Treatments & F.sambucinum Fs2 & F.sambucinum Fs3 & F.sambucinum Fs4 & Mean \\
\hline 1 & T. hamatum ÖT16 & $11.50 \mathrm{kt}$ & $12.63 \mathrm{jm}$ & $16.06 \mathrm{fg}$ & $13.40 \mathrm{c}$ \\
\hline 2 & T. virens KB31 & $11.50 \mathrm{kt}$ & $9.06 \mathrm{vx}$ & $11.06 \mathrm{mu}$ & $10.54 \mathrm{fg}$ \\
\hline 3 & T. viride VG19 & $10.94 \mathrm{mu}$ & $13.75 \mathrm{hj}$ & $15.50 \mathrm{fh}$ & $13.40 \mathrm{c}$ \\
\hline 4 & T. viride $V G 18$ & $12.50 \mathrm{jn}$ & $11.56 \mathrm{ks}$ & $17.13 \mathrm{ef}$ & $13.73 \mathrm{bc}$ \\
\hline 5 & T. harzianum LO52 & $10.13 \mathrm{rw}$ & $9.31 \mathrm{ux}$ & $10.81 \mathrm{nv}$ & $10.08 \mathrm{gh}$ \\
\hline 6 & T. harzianum TUZ16 & $9.38 \mathrm{u}$ & 8.50 wy & $10.50 \mathrm{pv}$ & $9.46 \mathrm{~h}$ \\
\hline 7 & T. strigosum LO8 & 12.31 jo & 12.8811 & $19.00 \mathrm{bd}$ & $14,73 \mathrm{~b}$ \\
\hline 8 & T. inhamatumKEB12 & $9.75 \mathrm{tx}$ & $9.31 \mathrm{ux}$ & $10.69 \mathrm{ov}$ & $9.92 \mathrm{gh}$ \\
\hline 9 & T. asperellum ÖT1 & $11.06 \mathrm{mu}$ & $12.00 \mathrm{jp}$ & $17.88 \mathrm{ce}$ & $13.64 \mathrm{c}$ \\
\hline 10 & T. gamsii VG47 & $11.75 \mathrm{kr}$ & $10.13 \mathrm{rw}$ & $13.001 \mathrm{k}$ & $11.63 \mathrm{de}$ \\
\hline 11 & T. tomentosum $V G 2$ & $10.69 \mathrm{ov}$ & 8.19 xy & $11.81 \mathrm{kr}$ & $10.23 \mathrm{gh}$ \\
\hline 12 & T. neokoningii A15 & $9.88 \mathrm{sx}$ & $15.56 \mathrm{fg}$ & $17.25 \mathrm{df}$ & $14.23 \mathrm{bc}$ \\
\hline 13 & T. atroviride VG3 & $11.50 \mathrm{kt}$ & 8.44 wy & $11.94 \mathrm{kq}$ & $10.63 \mathrm{eg}$ \\
\hline 14 & T. strigosum LO43 & $11.88 \mathrm{kr}$ & $11.19 \mathrm{lt}$ & $18.06 \mathrm{ce}$ & $13.71 \mathrm{bc}$ \\
\hline 15 & T. gamsii VG48 & $11.31 \mathrm{kt}$ & $10.19 \mathrm{qw}$ & 12.8811 & $11.46 \mathrm{df}$ \\
\hline 16 & Fludioxonil & $3.69 \mathrm{z}$ & $4.69 \mathrm{z}$ & $7.00 \mathrm{y}$ & 5.121 \\
\hline 17 & Azoxystrobin & $10.44 \mathrm{pv}$ & $10.63 \mathrm{ov}$ & $14.56 \mathrm{~g}_{1}$ & $11.87 \mathrm{~d}$ \\
\hline 18 & Control (+) & $19.13 \mathrm{bc}$ & $20.06 \mathrm{~b}$ & $23.81 \mathrm{a}$ & $21.00 \mathrm{a}$ \\
\hline 19 & Control (-) & 0.00 & 0.00 & 0.00 & 0.00 \\
\hline & Mean & $11.07 \mathrm{~b}$ & $11.00 \mathrm{~b}$ & $14.39 \mathrm{a}$ & 12.16 \\
\hline & CV\% & \multicolumn{4}{|c|}{10.56} \\
\hline & $\mathrm{LSD}_{0,05}$ & Treatment; $1.03 * *$ & \multicolumn{2}{|c|}{ Fs; $0.42 * *$} & Treatment x Fs $1.79 * *$ \\
\hline
\end{tabular}

$* * \mathrm{P}<0.01$. Levels not connected by same letter are significantly different

The effects of fungicides and isolates of Trichoderma on $F$. sambucinum isolates showed significant differences in terms of individual and mean values $(\mathrm{P}<0.01)$. The differences between the treatments were grouped by the LSD (LSMeans Differences Student's t) test (Table 2). The disease was observed at all tubers in replications inoculated with Fs2, Fs3, and Fs4 isolates of $F$. sambucinum and treated with antagonists and certain fungicides. However, the levels of influence were different. The disease severity in the positive control of Fs2, Fs3 and Fs4 isolates was the highest and it was 19.13, 20.06 and 23.81, respectively. Fludioxonil, a fungicide, was the most inhibitory treatment $(3.69,4.69$ and $7 \mathrm{~mm})$ on growth of all three isolates investigated (Fs2, Fs3 and Fs4). The inhibitory effect of Azoxystrobin followed the Fludioxonil as 10.44, 10.63 and $14.56 \mathrm{~mm}$. The most effective of Trichoderma species on Fs2 isolate was $T$. harzianum TUZ16 with $9.38 \mathrm{~mm}$. T. tomentosum VG2 was effective on Fs3 isolate with $8.19 \mathrm{~mm}$ and T. harzianum TUZ16 was effective on Fs4 isolate with 10.50 $\mathrm{mm}$. Fludioxonil was the most inhibitory fungicide on growth of all three isolates with an average of $5.12 \mathrm{~mm}$. Average growth of isolates with Azoxystrobin treatment was 11.87. Trichoderma harzianum TUZ16 $(9.46 \mathrm{~mm})$ was the most inhibitory species of 
Trichoderma species and followed by T. inhamatum $(9.92 \mathrm{~mm})$. Mean values of disease severity with $T$. neokoningii A15, T. strigosum LO43, T. asperellum ÖT1, T. hamatum ÖT16, T. viride VG19 and T. viride VG18 treatments were 14.23, 13.71, 13.64, 13.40, 13.40 and 13.73, respectively and placed in a separate group. Therefore, T. Strigosum LO8 (14.73) and T. neokoningii A15 (14.23) were the least effective species. The effect of treatments in preventing the disease was given in Figure 2.

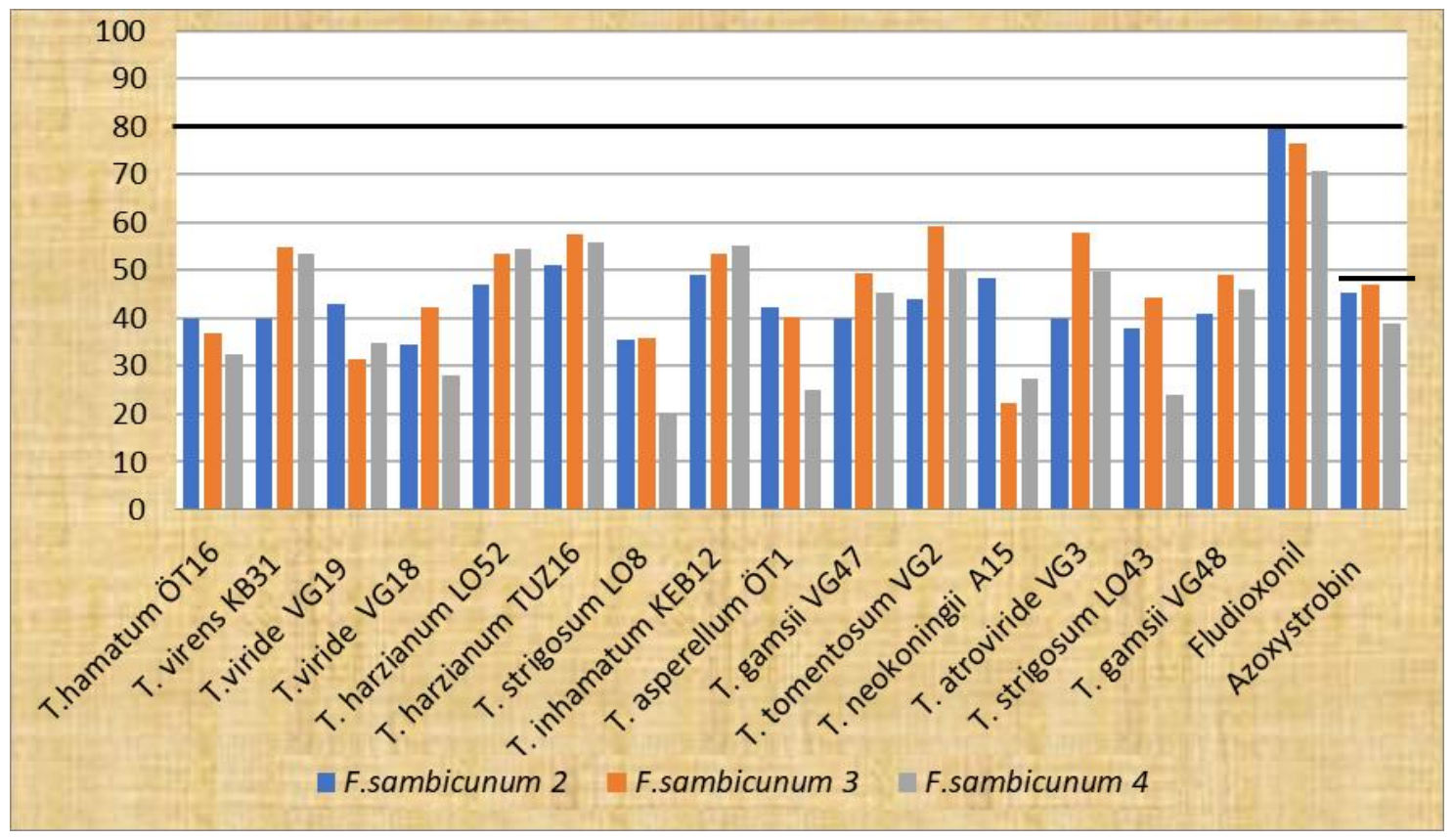

Figure 2. Effects of antagonists and fungicides on the prevention of disease in experiments with F. sambucinum Fs2, Fs3, and Fs 4 infected isolates

The influence ratio of treatments, comparing the positive control, ranged from 20.20 to $80.71 \%$. Average of the most effective treatments against three isolates of the pathogen was $75.97 \%$ for Fludioxonil, $54.82 \%$ for $T$. harzianum TUZ16, $49.21 \%$ for $T$. inhamatum KEB12, $51.73 \%$ for T. harzianum LO52, $51.22 \%$ for T. tomentosum VG2 and $49.21 \%$ for $T$. atroviride VG3, respectively. The appearances of some tubers cut in the evaluation phase after the treatments were shown in Figure 3.

Following the evaluation, the tissue pieces were taken from pathologically contaminated tubers that had been treated and had not been treated, and they were left to grow on the PDA medium. The growth of pathogen and Trichoderma species were observed.

\section{Discussion}

This study has been carried out in two phases. In the first phase, the interaction of pathogens and antagonists was measured in the PDA medium. In the second phase, the activity of antagonists was investigated with three isolates of pathogen in potato tubers. Fifteen isolates, 10 of which were Trichoderma species, were used in the study. Majority of these species have been reported as the first isolation in Turkey (Aydin and Turhan, 2009). Therefore, this type of Trichoderma was the first time studied against 
dry rot disease of potato caused by $F$. Sambucinum. According to our information, some Trichoderma species such as $T$. gamsii have been studied the first time against this pathogen in potato. Previous studies were mostly conducted with T. harzianum, T. viride and T. virens (Daami-Remadi et al., 2006; Sadfi et al., 2001; Ayed et al., 2006a; Cherif et al., 2001; Ru and Di., 2012; Wharton and Kirk, 2014).

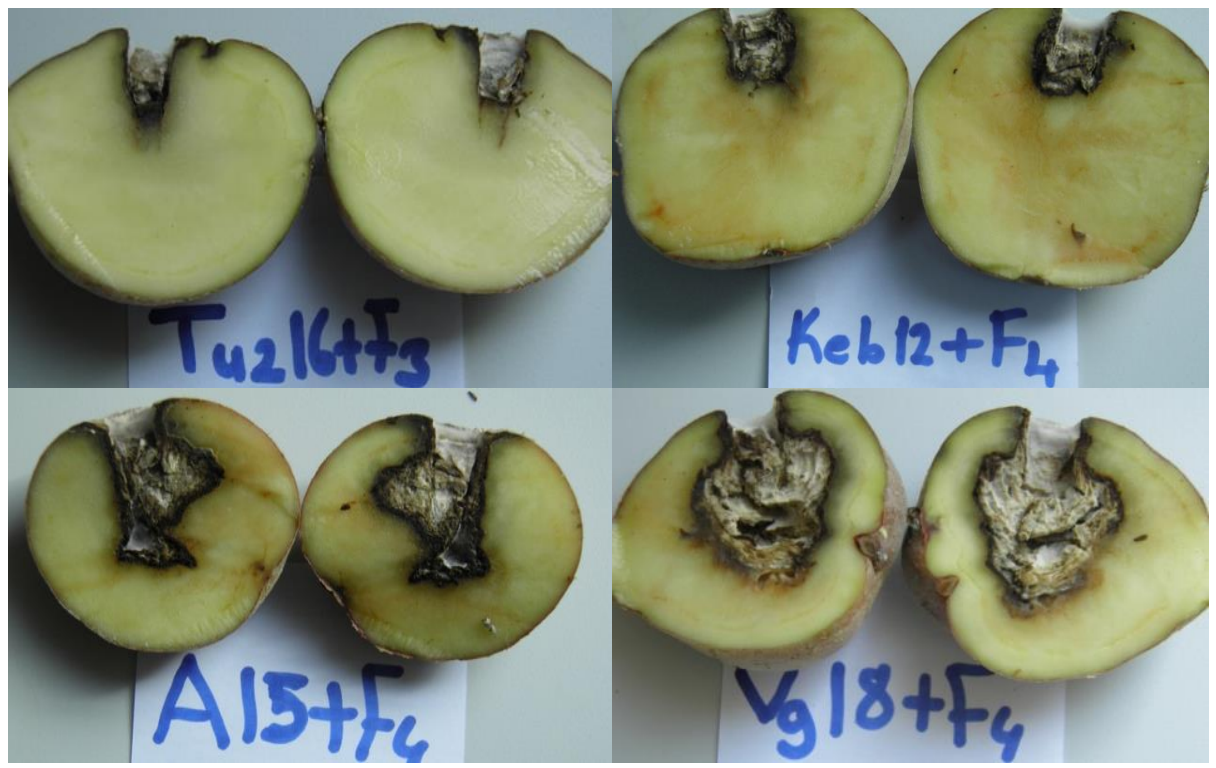

Figure 3. Appearance of disease developments in potato tubers, treated with antagonist and $F$. sambucinum isolates. Above: T. harzianum TUZ16- F. sambucinum 3 (the most inhibitory antagonist); T. inhamatum KEB12- F. sambucinum 4 (strong inhibitory antagonist). Below: T. viride VG18- F. sambucinum 4 (least inhibitory antagonist); T. neokoningii A15- F. sambucinum 4 (least inhibitory antagonist)

The results showed that some Trichoderma species reduced the dry rot disease that occurs in the tubers. The results of our study are in good agreement with some of previous studies. Daami-Remadi et al. (2006) reported that T. harzianum and T. viride control the disease at a certain rate. The efficiency of isolates from the same species on pathogen was close to each other both in nutrient medium and tubers. For example, $T$. harzianum TUZ16 and T. harzianum LO52 isolates obtained from different ecologies had SH and $\mathrm{H}$ values in the in vitro study (Table 1). The tuber study revealed that these two isolates of T. harzianum were effective in the penetration that ranged from 10.08 to $9.46 \mathrm{~mm}$ and at a rate between 54.82 and $51.73 \%$, respectively. The results indicated the differences between the species in activity against the pathogen, but the difference was little in Trichoderma isolates of the same species. The efficiency of T. hamatum ÖT16, T. viride VG18, T. viride VG19 and T. asperellum ÖT1 isolates against pathogen isolates was high ( $\mathrm{SH}$ and VSH) in duel cultures and PDA medium due to the mycoparasitzm, antibiotic and enzyme production. However, this effect has not sufficiently occurred in vivo conditions. The opposite situation can also occur. A Trichoderma isolate that is not sufficiently successful in laboratory conditions may act in vivo. Temperature and some other environmental factors play a great deal of influence on the antagonist activity. This may not adversely affect the biocontrol activity of Trichoderma species; but it may reduce the effectiveness over time. 
However, the most suitable environment to sustain the activity of a Trichoderma species should have similar temperature, moisture and nutrient values to the environment that the species isolated (Samuels, 2006).

T. gamsii VG47, $T$. gamsii VG48 and T. atrovide VG3 were successful in preventing the pathogen in both experiments. Our findings are in agreement with the previous studies (Cherif et al., 2001; Ru and Di, 2012; Wharton and Kirk, 2014). The results suggest that these antagonists have high compliance ability under various conditions. Establishment of field experiments with high performance isolates found in this study may lead to better results in terms of biological control against F. Sambucinum.

The efficacy of antagonists on the three isolates of $F$. sambucinum (Fs1, Fs2, Fs3) was not significantly different. The results of all experiments showed that the behavior of antagonists affecting the different isolates of pathogen was not significantly different.

After the evaluation, the tissues treated have been taken from the potatoes and planted on the PDA medium. In particular, Trichoderma species effective on pathogen were re-isolated (Fig. 4). This shows settling of antagonists into the tissue and continuing their activity. Trichoderma species have been reported to colonize and maintain their activity throughout the production season in various organs of plants (tubers, roots and stolons) (Harman, 2000; Howell, 2003; Aydın and Turhan, 2013).

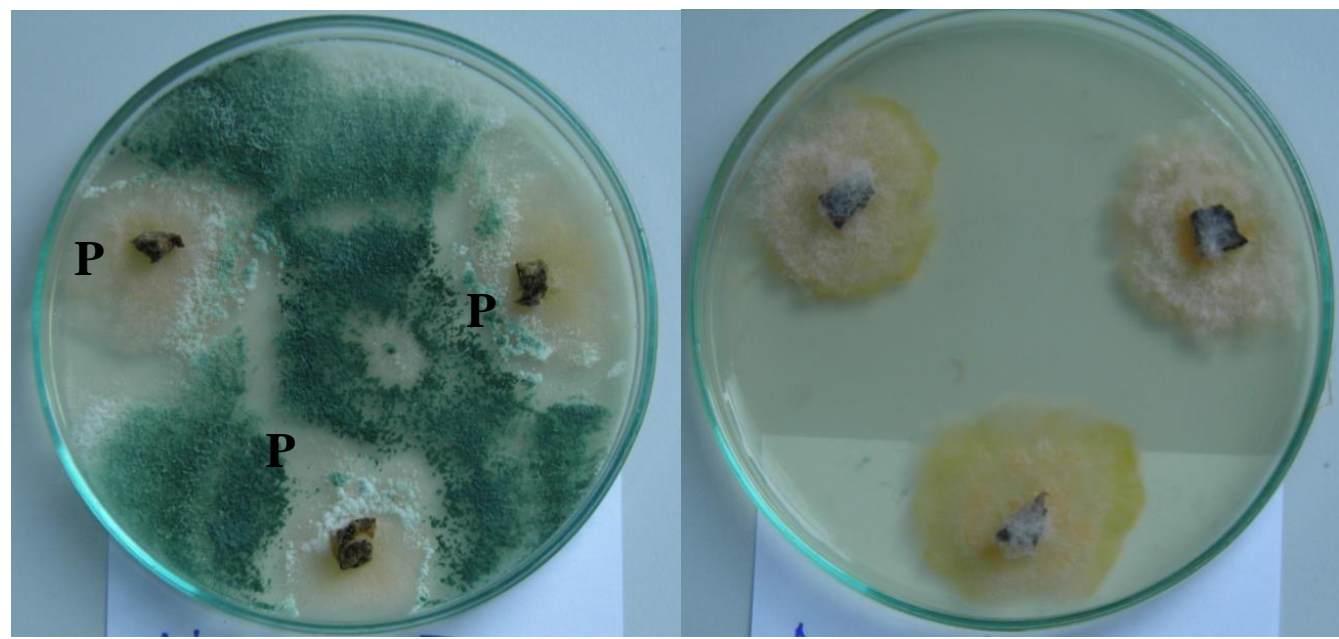

Figure 4. Fungus developing in potato tissues after evaluation. On the left: T. harzianum LO52 re-isolation in a treated tuber with green colour. On the right: reisolation image of $F$. sambucinum in pathogen with salmon colour-infected tuber). A: Antagonist, P: Pathogen

The fungicides with fludioxonil and azoxystrobin effective substances were used in the study. Fludioxonil has been identified as the most effective treatment. The activity of azoxystrobin was found to be low. Fludioxonil is effectively used against Rhizoctonia solani, another important tuberous disease of potatoes (Aydın and Turhan, 2009; Aydın et al., 2011). The fludioxonil has also been reported reducing the severity of dry rot disease of potatoes (Al- Mughrabi, 2010).

In contrast to previous studies, multiple isolates which were different from each other in terms of virulence were used in this study. Some Trichoderma species have demonstrated efficiency on all pathogen isolates in almost equal proportions. 


\section{Conclusion}

Dry rot disease caused by $F$. sambucinum is known an economically important field and a postharvest disease throughout the world. Biological control has recently gained great attention and shown significant potential to control the dry rot disease. The use of some Trichoderma such as T. viride VG18, T. asperellum ÖT1, T. harzianum TZ16, $T$. virens KB31 and T. inhamatum KEB12 successfully suppressed the dry rot in potatoes at different rates. The efficacies of some Trichoderma species and Fludioxonil treatments in preventing dry rot disease were higher compared to Azoxystrobin fungicide. The results obtained in this study showed that the use of Trichoderma isolates is an important approach in controlling the dry rot caused by $F$. sambucinum on potato tuber.

\section{REFERENCES}

[1] Adams, M. J., Lapwood, D. H. (1983): Transmission of Fusarium solani var. coeruleum and $F$. sulphureum from seed potatoes to progeny tubers in the field. - Ann. Appl. Biol. 103: 411-417.

[2] Al-Mughrabi, K. I. (2010): Biological control of Fusarium dry rot and other potato tuber diseases using Pseudomonas fluorescens and Enterobacter cloacae. - Biological Control 53: 280-284.

[3] Aydın, M. H., Turhan, G. (2009): Studies on Determination of Fungal Antagonists of Rhizoctonia solani. - Anadolu J. of AARI 19(2): 49-72.

[4] Aydin, M. H., Turhan, G. (2013): The Efficacy of Trichoderma Species against Rhizoctonia solani in Potato and Their Integration with Some Fungicides. - Anadolu J. of AARI 23(1): 12-30.

[5] Aydın, M. H., İnal, B. (2018): Comparative susceptibility of some commercial potato cultivars to Fusarium sambucinum and $F$. solani isolates causing tuber dry rot. - Applied Ecology and Environmental Research 16(4): 4879-4892.

[6] Aydın, M. H., Turhan, G., Göre, E. (2011): Determination of some antagonists efficiency on the viability and the formation of sclerotia of Rhizoctonia solani on potato tubers. Anadolu J. of AARI 21(2): 29-38.

[7] Aydın, M. H., Pala, F., Kaplan, C. (2016): Potato tuber sprout rot caused by Fusarium sambucinum in Turkey. - Scientific Papers. Series A. Agronomy 59: 189-193.

[8] Ayed, F., Daami-Remadi, M., Jabnoun-Khiareddine, H., Hibar, K., El Mahjoub, M. (2006a): Potato Vascular Fusarium wilt in Tunisia: incidence and biocontrol by Trichoderma spp. - Plant Pathol. J. 5: 92-98.

[9] Ayed, F., Daami-Remadi, M., Jabnoun-Khiareddine, H., El Mahjoub, M. (2006b): Effect of potato cultivars on incidence of Fusarium oxysporum f. sp. tuberosi and its transmission to progeny tubers. - Journal of Agronomy 5: 430-434.

[10] Bell, D. K., Weels, H. D., Markham, C. R. (1982): In vitro antagonism of Trichoderma species against six fungal plant pathogens. - Phytopathology 72: 379-382.

[11] Boosalis, M. G. (1964): Hyperparasitism. - Anual Review of Phytopathology 2: 363-376.

[12] Borca, I. D., Carmen, E. P. (2013): Studies regarding the morphological identification of Fusarium sambucinum Fuckel isolated from potato tubers. - ProEnvironment 6: 59-63.

[13] Carnegie, S. F., Cameron, A. M., Lindsay, D. A., Sharp, E., Nevison, I. M. (1998): The effect of treating seed potato tubers with benzimidazole, imidazole and phenylpyrrole fungicides on the control of rot and skin blemish diseases. - Ann. Appl. Biol. 133: 343363.

[14] Boyd, A. E. W. (1972): Potato storage diseases. - Rev. Plant Pathol. 51: 297-321. 
[15] Chaube, H. S., Mishra, D. S., Varshney, S., Singh, U. S. (2002): Biological control of plant pathogens by fungal antagonistic: Historical background, present status and future prospects. - Annu. Rev. Plant Pathol. 2: 1-42.

[16] Cherif, M., Omri, N., Hajlaoui, M. R., Mhamdi, M., Boubaker, A. (2001): Effect of some fungicides on Fusarium roseum var. sambucinum causing potato tuber dry rot and on Trichoderma antagonists. - Annales de I'INRAT 74: 131-149.

[17] Chet, I., Baker, R. (1981): Isolation and biocontrol potential of Trichoderma hamatum from soil naturally suppressive to Rhizoctonia solani. - Phytopathology 71: 286-290.

[18] Choiseul, J., Allen, L., Carnegie, SF., Darling, D. (2001): Fungi Causing Tuber Rots of Seed Potatoes in Storage. - In: Hay, R. K. M. (ed.) Scientific Review 1997-2000. Scottish Agricultural Science Agency, Edinburgh, UK, pp. 46-8.

[19] Cook, R. J., Baker, K. F. (1983): The Nature and Practice of Biological Control of Plant Pathogens. - APS, SZ Paul, Minnesota.

[20] Cullen, D. W., Toth, I. K., Pitkin, Y., Boonham, N., Walsh, K., Barker, I., Lees, A. K. (2005): Use of quantitative molecular diagnostic assays to investigate Fusarium dry rot in potato stocks and soil. - Phytopathology 95: 1462-1471.

[21] Daami-Remadi, M., Ayed, F., Jabnoun-Khiareddine, H., Hibar, K., El Mahjoub, M. (2006): Comparative susceptibility of some local potato cultivars to four Fusarium species causing tuber dry rot in Tunisia. - Journal of Plant Sciences 1(4): 306-314.

[22] Desjardins, A. E. (1995): Population structure of Gibberella pulicaris (anamorph Fusarium sambucinum) from potato tuber dry rot in North America and Europe. - Am. Potato J. 72: 145-156.

[23] Eken, C., Demirci, E., Sahin, F. (2000): Pathogenicity of the fungi determined on tubers from potato storages in Erzurum, Turkey. - Journal of Turkish Phytopathology 29: 61-69.

[24] Elad, Y. (2000): Biological control foliar pathogens by means of Trichoderma harzianum and potential modes of action. - Crop Protect. 19: 709-714.

[25] Elad, Y., Chet, I., Katan, J. (1980): Tricoderma harzianum a biocontrol agent effective against Sclerotium rolfsii and Rhizoctonia solani. - Phytopathology 70: 119-121.

[26] Gachango, E., Kirk, W., Wharton, P. S., Schafer, R. (2012): Evaluation and comparison of biocontrol and conventional fungicides for control of postharvest potato tuber diseases. - Biol. Control 63: 115-120.

[27] Gonzalez, C. F., Provin, E. M., Zhu, L., Ebbole, D. J. (2002): Independent and synergistic activity of synthetic peptides against thiabendazole-resistant Fusarium sambucinum. Phytopathology 92: 917-924.

[28] Hanson, L. E., Schwager, S. J.., Loria, R. (1996): Sensitivity to thiabendazole in Fusarium species associated with dry rot of potato. - Phytopathology 86: 378-384.

[29] Harman, G. E. (2000): Myths and dogmas of biocontrol. Changes in perceptions derived from research on Trichoderma harzianum T-22. - Plant Dis. 84: 377-393.

[30] Harman, G. E., Howell, C. R., Viterbo, A., Chet, I., Lorito, I. M. (2004): Trichoderma species - Opportunistic, avirulent plant symbionts. - Nature Rev. 2: 43-56.

[31] Hide, G. A., Read, P. J., Hall, S. M. (1992): Resistance to thiabendazole in Fusarium species isolated from potato tubers affected by dry rot. - Plant Pathol. 41:745-748.

[32] Hooker, W. J. (1983): Compendium of Potato Diseases. - American Phytopathological Society, Minnesota, USA.

[33] Howell, C. R. (2003): Mechanisms employed by Trichoderma species in the biological control of plant diseases: the history and evolution of current concepts. - Plant Dis. 87: 410.

[34] Jellis, G. J. (1975): Screening potato clones for resistance to dry rot (Fusarium solani var. coeruleurn). - Annals of Applied Biology 81: 417-418.

[35] Jellis, G. J., Starling, N. C. (1983): Resistance to powdery dry rot (Fusarium sulphureum) in potato tubers. - Potato Research 26: 295-301.

[36] Kredics, L., Antal, Z., Manczinger, L., Szekeres, A., Kevei, F., Nagy, E. (2003): Trichderma strains with biocontrol potential. - Food Technol. Biotechnol. 41(1) 37-42. 
[37] Langerfeld, L. (1979): Prüfung des Resistenzverhaltens von kar-toffelsorten gegenüber Fusarium coeruleum (Lib.) Sacc. - Potato Res. 22: 107-122.

[38] Lapwood, D. H., Read, P. J., Spokes, J. (1984): Methods for assessing the susceptibility of potato tubers of different cultivars to rotting by Erwinia carotovora subsp. atroseptica and carotovora. - Plant Pathology 33: 13-20.

[39] Lockwood, J. L. (1977): Fungistatis in soil. - Biol. Rev. 52: 1-43.

[40] Manczinger, L., Antal, Z., Kredics, L. (2002): Ecophysiology and breeding of ycoparacitic Trichoderma strains (a review). - Acta Microbiologica et Immunologica Hungarica 49: 1-14.

[41] Nelson, P. E., Toussoun, T. A., Cook, R. J. (1981): Fusarium: Diseases, Biology and Taxonomy. - The Pennsylvania State University Press, University Park, Pennsylvania.

[42] Nelson, P. E., Toussoun, T. A., Marsas, W. F. U. (1983): Fusarium species. An Illustrated Manual for Identification. - The Pennsylvania State Univ. Press, University Park, Pennsylvania.

[43] Peters, J. C., Lees, A. K., Cullen, D. W., Sullivan, L., Stroud, G. P., Cunnington, A. C. (2008): Characterization of Fusarium spp. responsible for causing dry rot of potato in Great Britain. - Plant Pathology 57: 262-271.

[44] Peters, R. D., Macdonald, I. K., MacIsaac, K. A., Woodworth, S. (2001): First report of thiabendazole-resistant isolates of Fusarium sambucinum infecting stored potatoes in Nova Scotia. - Canada Plant Disease 85: 1030.

[45] Ru, Z., Di, W. (2012): Trichoderma spp. from rhizosphere soil and their antagonism against Fusarium sambucinum. - African Journal of Biotechnology 11(18): 4180-4186.

[46] Sadfi, N., Cherif, M., Fliss, I., Boudabbous, A., Antoun, H. (2001): Evaluation of Bacillus isolates from salty soils and Bacillus thuringiensis strains for the biocontrol of Fusarium dry rot of potato tubers. - Journal of Plant Pathology 83: 101-118.

[47] Samuels, G. J. (2006): Trichoderma: Systematics, the sexual state, and ecology. Phytopathology 96(2): 195-206.

[48] Schisler, D. A., Slininger, P. J., Bothast, R. J. (1997): Effects of antagonists cell concentration and two-strain mixtures on biological control of Fusarium dry rot of potatoes. - Phytopathology 87: 177-183.

[49] Schisler, D. A., Burkhead, K. D., Slininger, P. J., Bothast, R. J. (1998): Selection, Characterization and Use of Microbial Antagonists for the Control of Fusarium Dry Rot of Potatoes. - In: Boland, G. J., Kuykendall, L. D. (eds.) Plant-Microbe Interactions and Biological Control. Marcel Dekker, New York, pp: 199-221.

[50] Secor, G. A., Sales, B. (2001): Fusarium Dry Rot and Fusarium Wilt. - In: Stevenson, W. R. et al. (eds.) Compendium of Potato Diseases. 2nd ed. The American Phytopathological Society, St. Paul, MN, pp. 23-25.

[51] Senter, L. H., Sanson, D. R., Corley, D. G., Tempesta, M. S., Rottinghaus, A. A., Rottinghaus, G. E. (1991): Cytotoxicity of trichothecene mycotoxins isolated from Fusarium sporotrichioides (MC-72083) and Fusarium sambucinum in baby hamster kidney (BHK-21) cells. - Mycopathology 113: 127-131.

[52] Stefańczyk, E., Sobkowiak, S., Brylińska, M., Śliwka, J. (2016): Diversity of Fusarium spp. associated with dry rot of potato tubers in Poland. - Eur J Plant Pathol. 145: 871884.

[53] Stevenson, W. R., Loria, R., Franc, G. D., Weingartner, D. P. (2001): Compendium of Potato Diseases. - APS Press, St. Paul, Minnesota, USA.

[54] Sun, X. J, BI, Y., Li, Y. C. Han, R. F., Yong-Hong, G. E. (2008): Postharvest chitosan treatment induces resistance in potato against Fusarium sulphureum. - Agric. Sci. China 7(5): 615-621.

[55] Turhan, G. (1990): Further hyperparasites of Rhizoctonia solani Kühn as promising candidates for biological control. - Zeitschrift für Pflanzenkrankheiten und Pflanzenschutz 97: 208-215. 
[56] Wastie, R. L., Stewart, H. E., Brown, J. (1989): Comparative susceptibility of some potato cultivars to dry rot caused by Fusarium sulphurum and Fusarium solani var. coeruleum. - Potato Research 32: 49-55.

[57] Wharton, P. S., Kirk, W. W. (2014): Evaluation of biological seed treatments in combination with management practices for the control of Fusarium dry rot of potato. Biological Control 73: 23-30.

[58] Whipps, J. M., McQuilken, M. P., Budge, S. P. (1993): Use of fungal antagonists for biocontrol of damping-off and Sclerotinia disease. - Pestic. Sci. 37: 309-313.

[59] Wilhelm, M. S. (1973): Principles of biological control of soil-borne plant disease. - Soil Biol. Biochem. 5: 729-737. 